\title{
Ethics and plagiarism in students' opinions: A case study from the Czech Republic
}

\author{
Ondřej Filipec \\ Palacký University in Olomouc, Czech Republic \\ Correspondence should be addressed to Ondřej Filipec (iD) ondrejfilipec@gmail.com \\ Received 6 July 2021; Revised 23 November 2021; Accepted 1 December 2021
}

\begin{abstract}
This article is about plagiarism from the perspective of university students. It presents data collected among 309 students at the Faculty of Law, Palacký University in Olomouc, to reveal attitudes of future lawyers towards the issue of plagiarism. The research follows previous research made at Mendel University in Brno. Next to the revealing attitudes of students towards plagiarism, the article compares results achieved at both institutions and tries to reveal the most critical factors leading to plagiarism. Moreover, data obtained at Palacký University are put into the broader theoretical context of research on plagiarism.
\end{abstract}

Keywords: Plagiarism, academic ethics, university students, Czech Republic

\section{Introduction}

The plagiarism issue is often discussed in the classrooms and public in relation to public officials and politicians. In 2018 alone, two government ministers in the Czech Republic were forced to resign due to plagiarism, making the creation of a new government after elections more complicated. However, lecturers at the universities are dealing with plagiarism much more frequently than mentioned in the media. And because plagiarism is one of the critical issues of modern education, it might well be considered "a litmus paper" of the quality of education in the Czech Republic and in other countries. Generally, we can claim that students who went for the title with the fraud and often plagiarized will have some deficiencies in some parts of the curriculum, not mentioning a lack of moral principles and violation of ethical standards. This article deals with plagiarism in students' opinions in legal education at the Faculty of Law, Palacký University in Olomouc, Czech Republic. It is an important issue, especially for students within this faculty. First, law students shall have a higher personal standard in respect to ethical standards and moral principles. Second, the legal education in the Czech Republic was damaged by the affair in Plzeň, where plagiarism happened on a very organized and institutionalized basis (Czech Radio, 2009), representing a worst-case scenario involving total failure of anti-plagiarism measures. Sadly, similar situations are not rare and can also be observed in different countries, as Starovoytova (2017) demonstrated.

The main subject of the research is the relationship of students at the Faculty of Law, Palacký University in Olomouc, towards plagiarism. The article is considered an exploratory case study with some defining elements. The research explores students' opinions on plagiarism (exploratory dimension) and finds the most important factors or variables influencing their views and perception (explanatory dimension). As a result, the first dimension focuses on the research question (RQ1): "What is and what is not considered by students as plagiarism, and what measures shall be taken to fight plagiarism?" The second dimension is aimed at discovering the most important variables influencing the perception of plagiarism. For that reason, the second research question (RQ2) is as follows: "What factors and variables are influencing the perception of students on plagiarism or their behavior leading to plagiarism?" Thus, in some aspects, the research will assess some key variables as introduced by Gerdeman, who identified five variables influencing 
dishonest conduct: Academic achievement, age, social activities, study field, and gender (Gerdeman, 2000). Hopefully, the response to both questions will lead to a better understanding of the phenomenon and indirectly contribute to the improvement of the education process and pedagogical attitude of the lecturers.

It is important to note that this study is not the only one in the Czech Republic. The research design was significantly inspired by the article written by Smolík et al. (2019). They researched plagiarism among first-year students at the Faculty of Regional Development and International Studies at Mendel University in Brno. To keep the consistency of research allowing comparison between both institutions, the author of this study used the same questionnaire with the same question as further described in the section dedicated to material and methods.

The article is divided into a classical structure of the journal. After the literature overview in the introduction, research is explained within the body of the article, followed by a section dedicated to materials and methods. This section if in detail presenting the research survey in order to allow potential replication of the research. In part dedicated to results, the author provides the outcomes of the survey and highlights the main findings. In the article's discussion section, results are compared with similar research executed by Smolík et al. (2019) and overall are put into the context of existing literature. As a result, the article is not only an empirical case study working with data from one institution but offers a comparison between two institutions and provides a valuable link to the existing state of knowledge on plagiarism within academia.

Many authors have researched plagiarism from various cultural environments. Noticeable is the attitude of "western authors" who focus on the USA, Canada, or Australia, including private and public universities or other Western countries, mainly the United Kingdom or Germany. These studies usually provide in-depth institutional analysis or a multi-campus comparison (see Brown \& Choong, 2005; Lynch et al., 2016; McCabe, 2005; Ural \& Sulak, 2012; Smyth \& Davis, 2004; Walker, 1998). However, there are also valuable studies comparing Western countries with Central European countries (Jereb et al., 2018). Multinational reflection also involving Asian or African countries is not an exception (Amiri \& Razmjoo, 2016; Batane, 2010; Bretag, 2016; Chen \& Chou, 2017; Ismail, 2018; Khairnar et al., 2019). Plagiarism is well researched also in Turkey, where Gokmenoglu highlighted the need to focus on plagiarism perception and views (Gokmenoglu, 2017). This is, however, the limit of the great number of research papers, and hopefully, this paper will partially contribute to closing the gap.

Within the academic environment, research is often focusing on two other areas. First is the identification and assessment of individual variables which are supportive of plagiarism (Alimorad, 2020; Bennett, 2005; Comas-Forgas \& Sureda-Negre, 2010; Hurych, 2012; Jareb et al., 2018; Kayaoğlu et al., 2015; McCabe \& Trevino 1997; Whitley et al., 1999) or even moderating variables, such as religion (Quah et al., 2012). Second, the area is plagiarism prevention and tools to counter plagiarism (Davis et al., 1992; Foltýnek et al. 2014; McCabe \& Trevino, 1993; Meuschke et al., 2018; Meuschke \& Gipp, 2013; Mudra \& Dlabolová, 2019; Walker, 2009).

Plagiarism is not only the issue of students, but covers the whole academia including researchers (Clarke 2006; Eret \& Gokmenoglu, 2010). That is why considerable amount of studies are devoted to the analysis of academic space (Juyal et al., 2015; Masic, 2012; Vasconcelos et al., 2009) or are going even beyond academia, to the areas such as translations (Şahin et al., 2015); litigation (Mawdsley \& Cumming, 2009), project studies (Geraldi, 2021), architecture (Youngsun \& Jaepil, 2020), music (Cameron, 2020), journalism (Kurambayev, 2020) and many other areas. As a short overview shows, plagiarism is a well researched topic and it is not the aim to provide a detailed overview about plagiarism, which is subject of various articles (see for example Husain et al., 2017) which provides details about actual state-of-affairs in the research on plagiarism.

\section{Materials and Methods}

Research results provided in this article are based on original data, which were collected among first-year students at the Faculty of Regional Development and International Studies of Mendel University in Brno by Smolík et al. (2019). This research conducted for this article has been inspired 
by the previous study and continued at the Faculty of Law, Palacký University in Olomouc, where a new - much bigger - batch of data was collected by the author. Primary data were collected via an online questionnaire, which was delivered to the students via emails and an e-board of the faculty. A voluntary questionnaire was available in the period between ninth of March 2020 and ninth April. 2020. It is important to note that there were two calls to fill out the questionnaire because the data collection process was interrupted by the outbreak of COVID-19 and the extraordinary situation students were facing. As of 15th of April 2020 faculty had 1439 students. Out of this number, the questionnaire was filled by 309 respondents (approx. $21 \%$ of the total). However, as shown further, the representation of individual years and study fields well reflects the structure of the students, so the issue of over/under-representation of some segments is absent.

As presented in Table 1, the share of respondents proportionally reflects the number of actual students. Students in the sixth or higher year of study are slightly more represented in the sample. However, in the remaining cases, under-representation or over-representation is negligible. As a result, the research sample mirrors the structure of the students.

Table 1

Student distribution among years of study

\begin{tabular}{lccc}
\hline Year of study & $\begin{array}{c}\text { Percentage (number) of } \\
\text { respondents }\end{array}$ & $\begin{array}{c}\text { Students at the faculty } \\
\text { (April 2020) }\end{array}$ & $\begin{array}{c}\text { Under/Overrepresentation } \\
\text { of sample compared to the } \\
\text { real proportion }\end{array}$ \\
\hline First & $28.2 \%(87)$ & $422(29.3 \%)$ & $-1.1 \%$ \\
\hline Second & $20.7 \%(64)$ & $290(20.1 \%)$ & $+0.6 \%$ \\
\hline Third & $18.8 \%(58)$ & $252(17.5 \%)$ & $+1.3 \%$ \\
\hline Fourth & $16.5 \%(51)$ & $208(14.5 \%)$ & $+2 \%$ \\
\hline Fifth & $10.4 \%(32)$ & $171(11.9 \%)$ & $-1.5 \%$ \\
\hline Sixth or higher & $5.5 \%(17)$ & $96(1.2 \%)$ & $+4.3 \%$ \\
\hline
\end{tabular}

Naturally, there are fewer students every year as the difficulty of the study is increasing. For this reason, first-year students account for $28,2 \%$ of the sample, and every following year, the proportion decreases to just $10,4 \%$ representation of the fifth-year students.

The questionnaire was composed of 19 questions to identify the segment (e. g. gender, field of study and year of study, origin of students). In one of the questions, students were presented with nine cases to determine whether the case was plagiarism or not, which is a method used in many questionnaires (see, for example, Robinson-Zañartu, Cook-Morales, Peña, Afshani \& Nguyen 2005). In some other question's students were asked about their own experience with plagiarism, opinions on cheating, and possible solutions. In the final sections, students were asked to agree or disagree with the presented statements on a Likert scale from totally disagree to totally agree: e. g. "my classmates are cheating," or "cheating is widespread at the faculty"; "it is easy to plagiarize without notice of my teachers" etc. Despite certain criticism of the Likert scale and sensitivity of the measurement (see, for example, Chomeya, 2010, pp.399-403; Lee et al., 2002, pp.295-306), the author is persuaded that the existing concept provided valuable data and use of the scale is entirely appropriate in the field of education (Joshi et al., 2015). The questionnaire was designed to identify key variables, identify student awareness about plagiarism, and provide students' perceptions. Students were also given a "Free window" to report issues related to plagiarism and provide anonymous feedback, which was very beneficial and, in practice, led to changes including anti-plagiarism measures at the faculty and guidelines for students.

Finally, it is important to add some institutional context. The research subject of this article is plagiarism which, together with fabrication, falsification, and data theft, are the most fundamental types of academic fraud (Pešek, 2014). One of the most known websites on plagiarism plagiarism.org, has a definition from the Merriam-Webster online dictionary referring to plagiarism as 1) To steal and pass off (the ideas or words of another) as one' own; 2) to use 
(another's production) without crediting the source; 3) to commit literary theft or 4) to present as new and original an idea or product derived from an existing source (plagiarism.org, 2017). As with any definition, its value depends on fully covering the whole scope of the defined subject. Its weakness comes from being too specific and leaving some forms out of the definition or too general, also involving forms that are not the case. For this reason, students at the Faculty of Law, Palacký University in Olomouc, during their first year, are taught a course "Study skills" with a definition of plagiarism based on "open elements," involving also very mild forms of plagiarism. The definition, which is introduced every year approximately to 400 students, is based on six key elements:

1) Object (what is being plagiarized? A text, it's part, sentences, thoughts...); which is

2) activity (used, copied, incorrectly paraphrased, stolen, borrowed...or some other inappropriate activity;

3) from the source (a book, textbook, article, speech...); by

4) subject (student, students...);

5) without complete, truthful, and appropriate reference (references are formal features in the form of citation norms); and

6) with or without intention to cheat (which is also the most subjective element of the definition) having to influence on the case classification.

As a result, in the case of plagiarism, "presumption of innocence" is changed to "presumption of guilt" unless the student is removing the guilt by creating appropriate and fully correct references. This means that while some forms of plagiarism may lead to a disciplinary punishment and potential expulsion from the study, other forms with soft or negligible character may lead to worse evaluation or just be ignored by the lecturer due to minor significance. This was well put in the following sentence: "Plagiarism itself, like cheating, includes a range of behaviors from the innocuous to the criminal..." (Blum, 2009, p.10). As researched by McCabe, plagiarism may be associated with many variants of cheating (see McCabe, 2005).

Next to the previously structured and during the seminar debated definition, the faculty is formally using a definition within its directive aimed at the standard of qualification works. Article 2 states that: "For the purpose of this regulation, plagiarism shall be defined as any case in which the author of a qualification thesis knowingly, whether directly or indirectly, and for any purpose, presents a published or unpublished work, a part of a work or an idea produced by somebody else so as to give the impression that the work or idea is one's own." (Palacký University in Olomouc, 2018). At this time, the definition is under review, and internal standards will most probably also specify cases regarded as plagiarism that are less obvious among students. The definitions of plagiarism vary but usually contain two dimensions: socio-ethical and legal, which might be accompanied by the scientific dimension in the case of academic plagiarism (Kuprata \& Menso, 2020). This is also the case of the Faculty of Law at Palacký University in Olomouc where both dimensions are explored during education.

\section{Results}

During the first year at the faculty, students of the study program "Law and legal science" pass a special course dedicated to studying skills. One of the seminars is directly dedicated to the issue of plagiarism and proper referencing. This is also the case of other programs, "Law in Public Administration" and "European Studies with focus on European Law" where "Scientific Propaedeutics" is taught. It is not surprising that $90,9 \%$ of the students claim that they are able to define what plagiarism is, contrary to $7,4 \%$ of students who are unable or 1,6 \% of students who do not know. Also, $77 \%$ of the students claim that they were introduced to the issue of plagiarism during the first year of the study, 16,5\% do not remember or don't know, and only 6,5\% answered "no." Except for eight people, almost all of those answering that they were introduced to the issue also responded that they could define plagiarism. Only 11 stated that they don't know whether 
they are able to define it, and three people said that they are unable to define it. This clearly demonstrates that seminars about plagiarism matter.

Nonetheless, the declared ability to define plagiarism may not fully match accurate recognition of plagiarism as some cases might be considered legitimate in the eyes of students due to lower sensitivity to the varieties of plagiarism. For that reason, students were given a question: "Are the following examples plagiarism? Please answer yes or no." Results are summarized in the following Table 2.

Table 2

What is plagiarism according to students

\begin{tabular}{lcc}
\hline \multirow{2}{*}{ Case description } & \multicolumn{2}{c}{ Plagiarism according to students $(f)$} \\
\cline { 3 - 3 } $\begin{array}{l}\text { 1) A student is submitting a work/assignment, which was } \\
\text { written by his friend, who gave him permission to use it as his } \\
\text { own work. }\end{array}$ & 172 & 137 \\
\hline $\begin{array}{l}\text { 2) A student retyped part of the book or the internet and } \\
\text { submitted it as his own work without providing reference to the } \\
\text { source. }\end{array}$ & 309 & 0
\end{tabular}

3) A student used part of the book or the internet while making small changes, for example, adding some notes, changing names, etc., without marking citations in the text, but the source is listed 164 145 in the final list of references.

\begin{tabular}{|c|c|c|}
\hline $\begin{array}{l}\text { 4) A student lets the work be created by someone else and is } \\
\text { presenting it as his own. }\end{array}$ & 230 & 79 \\
\hline $\begin{array}{l}\text { 5) A student is making paraphrasing without a source because it } \\
\text { is changing the majority of words and, as a result, also the } \\
\text { meaning of the whole text. }\end{array}$ & 139 & 170 \\
\hline $\begin{array}{l}\text { 6) A student is using invalid or missing citations in the text } \\
\text { (date, name, page). }\end{array}$ & 164 & 145 \\
\hline $\begin{array}{l}\text { 7) A student is changing just a few words from the original } \\
\text { resources and is not mentioning them (is making paraphrasis } \\
\text { without citation in the text). }\end{array}$ & 296 & 13 \\
\hline $\begin{array}{l}\text { 8) A student is copying huge parts of the text }(\operatorname{ctrl} C+C \operatorname{Ctrl} V) \\
\text { because there is a lack of time. }\end{array}$ & 303 & 6 \\
\hline $\begin{array}{l}\text { 9) A student is citing material from the interview without } \\
\text { providing a source. }\end{array}$ & 272 & 37 \\
\hline
\end{tabular}

From the above Table 2, it is evident that the perception of plagiarism among students is very narrow and covers mainly the most significant cases of plagiarism expressed in cases number two, eight, and seven, respectively. However, in other cases, a significant number of students had a tendency to label behavior, not as plagiarism. For example, approx. $44 \%$ of students believe that it is not plagiarism when a work has been written by someone else, but later they receive permission to use the work under their own name (case 1), or $47 \%$ of the students do not consider plagiarism with the use of invalid data or missing citation (case 6). This implies that next to the definition of plagiarism, students shall be within the education process also equipped with a practical demonstration to practice the ability to recognize less obvious forms.

Another part of the research focused on the causes of plagiarism. Here, two factors are dominating others (multiple answers were allowed). According to the students, the most important reason is that the student is in time pressure $(63.8 \%)$ or that the student is lazy $(62.8 \%)$. A slightly lower proportion (47.2\%) of students think that the cause is lack of knowledge, what is allowed and what not. One-third of students mentioned "too high requirements to pass the course," and $29.4 \%$ of students mentioned students' persuasion that plagiarism is useful and may 
lead to better results. One-fifth of students noted the absence of purpose: that student does not understand that the study process shall lead to independent critical thinking.

Another question was in the Likert scale (strongly agree, agree, I don't know, disagree, strongly disagree). Students had to evaluate statements related to plagiarism. The answer "I don't know" was most frequent in two cases as a response to the statement that 1) "My classmates are plagiarizing" (50\% of students) and 2) that "it is very easy to plagiarize without realization of my teacher" (44.6\%). Regarding the first statement, just three students answered "strongly agree," and the other 39 students (12.6\%) agreed. As mentioned, around 50\% of students answered "I don't know," and almost $38 \%$ disagreed with the statement that classmates are plagiarizing. Regarding the second statement, the "I don't know" answer (44.6\%) was followed by disagreement (55.4\%), while only a minority of students agreed that it is easy to plagiarize without the realization of the teacher $(10 \%)$. The majority of students $(66.3 \%)$ strongly disagree that "Academic dishonesty is acceptable unless you're caught.". Students were divided regarding some statements. For example, on the statement that: "Teaches are regularly warning about the plagiarism" in total 78 students (25\%) provided negative answers compared to that positive $(63 \%)$ or "just" 53 students (15\%) agreed, that "cheating is an issue at the faculty". Overall, such results are not very surprising. The majority of students consider plagiarism as something negative or at least have a benevolent attitude. However, data also suggests that there is several students having personal experience with plagiarism and a less critical attitude.

The aim of this article is to reveal factors and variables behind attitudes towards plagiarism. For this reason, a sample of respondents is presented, and then individual variables are put into context. As mentioned earlier, data collection was conducted between 9. March 2020 and 9. April 2020.In total 309 respondents filled out the online questionnaire, out of which 109 were men and 200 were women. The number of surveyed respondents counts approx. for $21 \%$ of the total.

It would be interesting to know how the length of the study influences the perception of plagiarism. On the one hand, first-year students are during the first semester introduced to the study with the special course "Introduction to study," where one of the seminars is dedicated to the issue of plagiarism and correct referencing. Because of this, younger students shall be more aware of the issue than students more advanced in their studies. On the other hand, it might be expected that advanced students lost their initial information given during the first year; however, they have undertaken the socialization process and are more accommodating in their stances regarding plagiarism.

Just $8.7 \%$ of students have their own personal experience with plagiarism during studies (89\% had no experience and $2.3 \%$ replied that they don't know). This answer is interesting when confronted with another question, whether students ever cheated (plagiarized). In total, 11.7\% reported that yes, another $8.4 \%$ did not want to reply to the question, and $79.9 \%$ replied "no." What factors are supportive of cheating?

In total, 62 students replied that they cheated or that they did not want to reply. Out of this number, there are 23 students from the first year, 13 from the second year, 6 from the third year, 10 from the fourth year, 6 from the fifth year and 4 from the higher years of study. Suppose we consider the relative proportion of the students among individual years. In that case, we can rule out the tendency that increasing the duration of the study increases the likelihood of cheating. From the above-presented data, it seems that "cheaters" are overrepresented among first-year students. This might be caused by the low ability to distinguish between less clear forms of plagiarism, which respondents later recognized, most probably after having a special seminar on plagiarism.

Interesting might be the role of gender. Among 309 respondents, there were 200 women $(64.7 \%)$. Women represent 32 out of 62 respondents who admitted cheating or did not want to respond to the question, roughly $51.6 \%$. It might indicate that women are, on average cheating less than men. However, the dependent variable is declared. It means that there might be a significant proportion of women who did not respondent truthfully on the question. On the other side, a significant proportion of men admitted cheating and had less reservation to declare it. As noted, 
for example by Walker, it is important to distinguish between what students do and what students say they do (Walker, 2009). If we filter out all those who did not want to respond on the question, we have 32 people who declared cheating. Out of them are approx. 53\% men, which does not change perception much. The role of gender in relation to cheating is very interesting and, as such, deserves more attention.

After assessing existing literature about gender and plagiarism in their article Jereb, Uhr et al. (2018) found inconclusiveness of scientific literature. While some studies (including their own) found differences among gender (for example, Brown \& Choong, 2005; Davies et al., 1992; Smyth \& Davis, 2004; Whitley et al., 1999), others discovered no significance (Crown \& Spiller, 1998; Roig \& Caso, 2005). For this reason, it is worth contextualizing answers to question 7 (summarized in table 3 ) in the context of gender.

Table 3

The influence of gender on perception of plagiarism

\begin{tabular}{|c|c|c|}
\hline \multirow[t]{2}{*}{ Case description } & \multicolumn{2}{|c|}{$\begin{array}{l}\text { Plagiarism according to students (F: } \\
\text { Female; } M: \text { Male) }\end{array}$} \\
\hline & Yes & No \\
\hline \multirow{3}{*}{$\begin{array}{l}\text { A student is submitting a work/assignment which was } \\
\text { written by his friend, who gave him permission to use it as his } \\
\text { own work }\end{array}$} & 172 & 137 \\
\hline & F: $105(52.5 \%)$ & F: $95(47.5 \%)$ \\
\hline & M: $67(61.5 \%)$ & M: $42(38.5 \%)$ \\
\hline \multirow{3}{*}{$\begin{array}{l}\text { A student retyped part of the book or the internet and } \\
\text { submitted it as his own work without providing reference to } \\
\text { the source }\end{array}$} & 309 & \multirow{3}{*}{0} \\
\hline & F: $200(100 \%)$ & \\
\hline & M: $109(100 \%)$ & \\
\hline \multirow{3}{*}{$\begin{array}{l}\text { A student used part of the book or the internet while making } \\
\text { small changes, for example, adding some notes, changing } \\
\text { names, etc., without marking citation in the text, but the source } \\
\text { is listed in the final list of references }\end{array}$} & 164 & 145 \\
\hline & $\mathrm{F}: 111(55.5 \%)$ & F: $89(44.5 \%)$ \\
\hline & M: $53(48.6 \%)$ & M: 56 (51.4\%) \\
\hline \multirow{3}{*}{$\begin{array}{l}\text { A student let the work be created by someone else and is } \\
\text { presenting it as his own }\end{array}$} & 230 & 79 \\
\hline & F: $145(72.5 \%)$ & F: $55(27.5 \%)$ \\
\hline & M: $85(78 \%)$ & M: $24(22 \%)$ \\
\hline \multirow{3}{*}{$\begin{array}{l}\text { A student is making paraphrasing without source, because } \\
\text { he/she is changing the majority of words and, as a result, also } \\
\text { the meaning of the whole text }\end{array}$} & 139 & 170 \\
\hline & F: $95(47.5 \%)$ & $\mathrm{F}: 105(52,5 \%)$ \\
\hline & M: $44(40.4 \%)$ & M: $65(59.6 \%)$ \\
\hline \multirow{3}{*}{$\begin{array}{l}\text { A student is using invalid or missing citations in the text (date, } \\
\text { name, page) }\end{array}$} & 164 & 145 \\
\hline & F: $104(52 \%)$ & F: $96(48 \%)$ \\
\hline & M: $60(55 \%)$ & M: $49(45 \%)$ \\
\hline \multirow{3}{*}{$\begin{array}{l}\text { A student is changing just a few words from the original } \\
\text { resources and is not mentioning them (is making paraphrasis } \\
\text { without citation in the text) }\end{array}$} & 296 & 13 \\
\hline & F: $192(96 \%)$ & F: $8(4 \%)$ \\
\hline & M: $104(95.4 \%)$ & M: $5(4.6 \%)$ \\
\hline \multirow{3}{*}{$\begin{array}{l}\text { A student is copying huge parts of the text }(\operatorname{ctrl} C+C \operatorname{ctrl} V) \\
\text { because there is a lack of time }\end{array}$} & 303 & 6 \\
\hline & F: $196(98 \%)$ & F: $4(2 \%)$ \\
\hline & M: $107(98 \%)$ & M: $2(2 \%)$ \\
\hline \multirow{3}{*}{$\begin{array}{l}\text { A student is citing material from the interview without } \\
\text { providing source }\end{array}$} & 272 & 37 \\
\hline & F: $182(91 \%)$ & F: $18(9 \%)$ \\
\hline & M: $90(82.5 \%)$ & M: $17(17.5 \%)$ \\
\hline
\end{tabular}

\section{Discussion}

What does the data about students in Olomouc show when compared with similar research in Brno? And how do the results fit into the ongoing debate? First, it is surprising that the values are very similar, especially regarding the perception of plagiarism. It seems that a slightly higher percentage of students in Olomouc are able to define plagiarism. Or at least, they seem to be more 
confident when it comes to the definition. However, as shown in Table 3, the declared ability to define plagiarism may not match the correct perception of what shall be considered plagiarism and what not. Also, answer to two other questions shall not be taken normatively. While students in Brno declared a greater share of personal cheating, students in Olomouc declared a much higher percentage about experience dealing with plagiarism during their studies. Many factors may have influenced these numbers, including the sense of community (plagiarism is solved and information about it easily spread among students in the community), different personality types and profiles of people attending different types of studies, etc. Nonetheless, it seems that plagiarism at Mendel University is more often pointed at the lectures. The result is provided in Table 4.

Table 4

Comparing students from Brno and Olomouc (adapted from Smolík et al. (2019))

\begin{tabular}{|c|c|c|}
\hline Criterium & $\begin{array}{l}\text { Faculty of Regional } \\
\text { Development } \\
\text { and International Studies, } \\
\text { Mendel University in Brno }\end{array}$ & $\begin{array}{l}\text { Faculty of Law, Palacký } \\
\text { University in Olomouc }\end{array}$ \\
\hline N (sample) & 125 (First year only) & $\begin{array}{l}309 \text { students (87 first-year } \\
\text { only) }\end{array}$ \\
\hline Collected & May 2018 & March and April 2020 \\
\hline $\begin{array}{l}\text { Do you think you could define } \\
\text { plagiarism? }\end{array}$ & $83 \%$ I think so & $\begin{array}{l}90,4 \% \text { I think so; } 92 \% \text { for first- } \\
\text { year only }\end{array}$ \\
\hline Have you ever cheated? & $28 \%$ Yes & $\begin{array}{l}11,6 \% \text { Yes; } 13,8 \% \text { for first- } \\
\text { year only }\end{array}$ \\
\hline $\begin{array}{l}\text { Do you have personal } \\
\text { experience with dealing with } \\
\text { plagiarism during your } \\
\text { studies? }\end{array}$ & $2 \%$ Yes & $\begin{array}{l}8,7 \% \text { Yes; } 6,9 \% \text { for first-year } \\
\text { only }\end{array}$ \\
\hline My classmates plagiarize. & $15 \%$ Agree & $\begin{array}{l}13,6 \% \text { Agree; } 13,8 \% \text { for first- } \\
\text { year only }\end{array}$ \\
\hline $\begin{array}{l}\text { Cheating at our faculty is } \\
\text { widespread. }\end{array}$ & $14 \%$ Agree & $\begin{array}{l}17,1 \% \text { Agree; } 11,5 \% \text { for first- } \\
\text { year only }\end{array}$ \\
\hline $\begin{array}{l}\text { Academic dishonesty is } \\
\text { acceptable unless you're } \\
\text { caught. }\end{array}$ & $11 \%$ Agree & $\begin{array}{l}6,1 \% \text { Agree; } 12,6 \% \text { for first- } \\
\text { year only }\end{array}$ \\
\hline $\begin{array}{l}\text { Most pedagogues point out } \\
\text { plagiarism } \\
\text { during lectures. }\end{array}$ & 66 \% Agree & $\begin{array}{l}25,2 \% \text { Agree; } 41,4 \% \text { for first- } \\
\text { year only }\end{array}$ \\
\hline $\begin{array}{l}\text { I want our faculty to have a } \\
\text { document that defines the } \\
\text { citation requirements. }\end{array}$ & 88 \% Agree & $\begin{array}{l}82,8 \% \text { Agree; } 86,2 \% \text { for first- } \\
\text { year only }\end{array}$ \\
\hline $\begin{array}{l}\text { It is easy to plagiarize without } \\
\text { my teacher finding out. }\end{array}$ & 11 \% Agree & $\begin{array}{l}10 \% \text { Agree; } 12,6 \% \text { for first- } \\
\text { year only }\end{array}$ \\
\hline
\end{tabular}

The above comparison is interesting also just for the case of Olomouc as there is an obvious difference between first-year students and a sample of all students. Some opinions are getting stronger through time as experience is collected. The most visible drop is in the cases of pointing out plagiarism during lectures. Here students' perceptions might be under the influence of the "study skills course" of the first year. Students are getting critical of academic dishonesty and the possibility of plagiarizing without the realization of the teacher. However, at the same time, they are getting "intoxicated" with experience as they, in the increased share, think that cheating is 
widespread. Again, perception matters, and experience with plagiarism in a majority of cases leads to stronger opinions on plagiarism and increased perceptions that others are cheating. It is a sort of paradox because this view might be a decisive factor in plagiarizing. This implies that advancement in the study process tends to challenge personal integrity's "breaking point" when realizing that someone plagiarizes without punishment.

A great part of the solution is smart regulation, which might be inspired by top universities dealing with plagiarism and developed complex strategies. (see, for example, Oxford University, 2020a). Next to strategy, Oxford University also has a very user-friendly website for students regarding plagiarism, involving examples and a clear definition: Plagiarism is presenting someone else's work or ideas as your own, with or without their consent, by incorporating it into your work without full acknowledgment. All published and unpublished material, whether in manuscript, printed or electronic form, is covered under this definition. Plagiarism may be intentional or reckless, or unintentional. Under the regulations for examinations, intentional or reckless plagiarism is a disciplinary offense." (Oxford University, 2020b). The definition of Harvard university is shorter: Plagiarism is the theft of someone else's ideas and work. It is the incorporation of facts, ideas, or specific language that are not common knowledge, are taken from another source, and are not properly cited" (Harvard University, 2020). However, this short definition is also accompanied by an explanation dealing with various forms of cheating. Most visible is the offense of duplicate assignments and submission of work more than once.

Unlike Oxford or Harvard, other universities face new challenges. The modern era brought students unprecedented opportunities to cheat (see, for example, Jereb, Perc et al. (2018). Information is just "several clicks away" and might be simply copied with $\mathrm{Ctrl}+\mathrm{C}$ and $\mathrm{Ctrl}+\mathrm{V}$ function as invented by Larry Tesler. Moreover, millions of resources are online and well available, which is increasing demands on those who are evaluating the works of students, despite progressing the development of anti-plagiarism software and online application for originality verification or national repository (see Foltýnek et al., 2014; Mudra \& Dlabolová, 2019). The internet also stimulated the growth of agencies and individuals who are offering paid services for students. These actors just offer "preparation of materials" for a thesis or seminar essay; however, in reality, prepared materials are very close to finalized work submitted by students for evaluation. This new environment is also well reflected in the questionnaire aimed at revealing the opinions of students.

Most important, institutional factors, regulations, anti-plagiarism software, and other measures are playing an essential role (as pointed out by many: Meuschke et al., 2018; Mudra \& Dlabolová, 2019; Walker, 2009), but it is important to note that decision to plagiarize is also strongly dependent on personal factors. Next to the build-up of preventive and repressive tools, it is necessary to create an environment vital for positive attitudes among students towards education and its activities under the narrative that students are primarily learning to benefit themselves, not to satisfy the requirements of the teacher. Here, the appeal on teachers came to implement students' positive attitude, sense of responsibility, and values, which can invoke the voice of conscience. As put well by Hurych (2012): "when an author is lacking the desire to spread the message, when is not felling as a messenger, then plagiatorship might be prevented only by the voice of conscience or the threat of being revealed" (Hurych, 2012, p.12). This happens more likely with a personal and individual approach to the students, respecting the margins of professionality. For example, stressed by Paul Ernest in his article dedicated to the teachers of mathematics (Ernest 2019), teaching is an ethical profession. This fundamental consideration turns much more significant when teaching about ethics and plagiarism.

\section{Conclusion}

One of the most important findings is that students' perception of plagiarism is limited to its most obvious forms, such as copying from the book/source without referencing the source. However, other forms of less grave violation of academic standards or inappropriate referencing received much less attention among students and are not considered plagiarism by a significant proportion 
of students. Probably the most important revelation of research is that $44.3 \%$ of students are not considering as plagiarism the case in which a friend, who originally wrote the work, has given permission to the student to use it as his/her own work. Approximately a similar proportion of students do not consider the use of incomplete or missing citations in the text as plagiarism.

The explanatory part of this article dealt with the most important variables influencing students' perception of plagiarism. Especially the length of the study, gender and previous personal experience with plagiarism (cheating) was discussed. The latest variable was discussed in the form of both dependent and independent variables. The length of the study does have the same impact on the perception of plagiarism, even though students who admitted cheating are more present among first-year students. This is most probably due to their previous lack of knowledge about the essence of plagiarism. Much more interesting is the issue of gender, where men declared cheating much often than women. The article also revealed that the declared previous personal involvement in cheating influenced the perception of others as cheaters. These results are in line with research conducted by Newstead et al. (1996), who also claim that plagiarism is more frequent among boys, among younger students, and lower performance.

Above mentioned findings have implications for the pedagogical approach. First, it is necessary to open the plagiarism issue during the first year as data shows that seminars about plagiarism matter. However, defining plagiarism is not enough. Students shall be driven to practical recognition of less obvious forms of plagiarism and improve their own sensitivity in plagiarism detection. Second, it is up to the lecturer to stimulate an environment that will be unfriendly to plagiarism. Those who plagiarize often think that others are cheating too. It is up to the lecturer to communicate openly about plagiarism that plagiarism is not a norm. This might be supported by high level of own academic integrity, professional attitude motivating students and the use of proportionate punishments in the case of plagiarism detection.

\section{References}

Alimorad, Z. (2020). Examining the effect of gender and educational level on iranian efl graduate student's perceived reasons for committing plagiarism. GiST Education and Learning Research Journal, 20, 109-133. https:// doi.org/10.26817/16925777.769

Amiri, F., \& Razmjoo, S. A. (2016). On Iranian EFL undergraduate students' perceptions of plagiarism. Journal of Academic Ethics, 14(2), 115-131. https:/ / doi.org/10.1007/s10805-015-9245-3

Batane, T. (2010). Turning to Turnitin to fight plagiarism among university students educational. Technology $\mathcal{E}$ Society, 13(2), 1-12.

Bennett, R. (2005). Factors associated with student plagiarism in a post-1992 university. Assessment $\mathcal{E}$ Evaluation in Higher Education, 30(2), 137-162. https:// doi.org/10.1080/0260293042000264244

Blum, S. D. (2009). My word! Plagiarism and college culture. Cornell University Press.

Bretag, T. (2016). Handbook of academic integrity. Springer Singapore.

Brown, B. S., \& Choong, P. (2005). An investigation of academic dishonesty among business students at public and private United States Universities. International Journal of Management, 22(2), 201-214.

Cameron, S. (2020). An economic approach to the plagiarism of music. Palgrave Macmillan. https://doi.org/10.5659/JAIK_PD.2020.36.5.11

Chen, Y. \& Chou, C. (2017). 'Are We on the same page? College Student's and Faculty's Perception of Student Plagiarism in Taiwan', Ethics $\mathcal{E}$ Behavior, Vol. 27, No. 1, pp. 1-21. https:// doi.org/10.1080/10508422.2015.1123630

Chomeya, R. (2010). Quality of psychology test between likert scale 5 and 6 points. Journal of Social Sciences, 6(3), 399-403. https:/ / doi.org/10.3844/jssp.2010.399.403

Clarke, R. (2006). 'Plagiarism by Academics: More Complex Than It Seems,' Journal of the Association for Information Systems, Vol. 7, No. 1, pp. 91-121. https://doi.org/10.17705/1jais.00081

Comas-Forgas, R., \& Sureda-Negre, J. (2010). Academic plagiarism: explanatory factors from students' perspective. Journal of Academic Ethics, 8(3), 217-232. https:// doi.org/10.1007/s10805-010-9121-0

Crown, D. F. \& Spiller, M. S. (1998). Learning from the literature on collegiate cheating: A review of empirical research. Journal of Business Ethics, 17(6), 683-700. 
Czech Radio. (2009). The School for Scandal: serious malpractice uncovered at Plzeň Law Faculty. Radio Prague International. https://english.radio.cz/school-scandal-serious-malpractice-uncovered-plzen-lawfaculty-8580340

Davis, S. F., Grover, C. A., Becker, A. H., \& McGregor, L. N. (1992). Academic dishonesty: Prevalence, determinants, techniques, and punishments. Teaching of Psychology, 19, 16-20. https:// doi.org/10.3758/BF03334151

Eret, E. \& Gokmenoglu, T. (2010). Plagiarism in higher education: A case study with prospective academicians. Procedia Social and Behavioral Sciences, 2, 3303-3307. https://doi.org/10.1016/j.sbspro.2010.03.505

Ernest, P. (2019). The ethical obligations of the mathematics teacher. Journal of Pedagogical Research, 3(1), 8091. https:/ / doi.org/10.33902/JPR.2019.6

Foltýnek, T., Kravjar J. \& Clendinning I. (2014). Case study: Policies, strategies and responses to plagiarism in Slovakia. Journal on Efficiency and Responsibility in Education and Science, 7(1), 19-25. https:/ / doi.org/10.7160/eriesj.2014.070104

Geraldi, J. (2021). 'Plagiarism in Project Studies', Project Management Journal, 52(1), 3-10. https:// doi.org/10.1177/8756972820982443

Gerdeman, R. D. (2000). Academic dishonesty and the community college. ERIC Digest, ED447840.

Gokmenoglu, T. (2017). A review of literature: Plagiarism in the papers of Turkish context. Higher Education Studies, 7(3), 161-170.

Harvard University. (2020). Academic integrity. https://extension.harvard.edu/for-students/studentpolicies-conduct/academic-integrity/

Hurych, E. (2012). Plagiát - selhání jednotlivce či přirozený produkt systému? [Plagiarism - An Individual Failure or a Natural Product of the System?]. E-Logos Electronic Journal For Philosphy, 9, 2-14. https:/ / doi.org/10.18267/j.e-logos.323

Husain, M. F., Al-Shaibani S. K. G. \& Mahfoodh, A. H. O. (2017). Perceptions of and attitudes towards plagiarism and factors contributing to plagiarism: A review of studies. Journal of Academic Ethics, 15(2), 167-195.

Ismail, K. H. (2018). Perceptions of plagiarism among medical and nursing students in Erbil, Iraq. Sultan Qaboos University Medical Journal, 18(2), 196-201. https:/ / doi.org/10.18295/squmj.2018.18.02.012

Jereb, E., Perc, M., Lämmlein, B., Jerebic, J., Urh, M., Podbregar, I. \& Šprajc, P. (2018). Factors influencing plagiarism in higher education: A comparison of German and Slovene students. PLoS One, 13(8), 1-16. https:// doi.org/10.1371/journal.pone.0202252

Jereb, E., Uhr, M., Jerebic, J. \& Šprajc, P. (2018). Gender differences and the awareness of plagiarism in higher education. Social Psychology of Education, 21, 409-426. https:// doi.org/10.1007/s11218-017-9421-y

Joshi, A., Kale, S., Chandel, S. \& Pal, D. K. (2015). Likert scale: Explored and explained. Current Journal of Applied Science and Technology, 7(4), 396-403. https://doi.org/10.9734/BJAST/2015/14975

Juyal, D., Thawani, V. \& Thaledi, S. (2015). Plagiarism: An egregious form of misconduct. North American Journal of Medical Sciences, 7(2), 77-80.

Kayaoğlu, N. M., Erbay, Ş., Flitner, C. \& Saltaş, D. (2015). Examining student's perceptions of plagiarism: A cross-cultural study at tertiary level. Journal of Further and Higher Education, 40(5), 682-805. https:/ / doi.org/10.1080/0309877X.2015.1014320

Khairnar, R. M., Wadgave, U., Shah, J. S., Shah, S., Jain, V. M. \& Kumbhar, S. (2019). Survey on the attitude of dental professions about plagiarism in Maharashtra, India. Perspectives in Clinical Research, 10(1), 9-14. https:/ / doi.org/10.4103/picr.PICR_141_17

Kuprata, N. \& Menso, I. (2020). Academic plagiarism and self plagiarism as elements of violation of academic integrity. Human Studies. Series of Pedagogy, 11(43), 75-90. https://doi.org/10.24919/24132039.11/43.220455

Kurambayev, B. (2020). The Causes and Consequences of Plagiarism by Journalist in Central Asia. Asian Studies Review, 44(4), 691-708. https:/ / doi.org/10.1080/10357823.2020.1747982

Lee, J. W., Jones, P. S., Mineama Y. \& Zhang, E. X. (2002). Cultural differences in responses to a likert scale. Research in Nursing \& Health, 25(4), 295-306. https:/ / doi.org/10.1002/nur.10041

Lynch, J., Everett, B., Ramjan, M. L., Callins, R. \& Glew, P. (2016). Plagiarism in nursing education: an integrative review. PubMed, 26(19, 20), 2845-2864. https:/ / doi.org/10.1111/jocn.13629

Masic, I. (2012). Plagiarism in scientific publishing. Acta Informatica Medica, 20(4), 208-213. https:// doi.org/10.5455/aim.2012.20.208-213

Mawdsley, R. D. \& Cumming J. (2009). Plagiarism litigation trends in the USA and Australia. Education and Law, 20(3), 209-234. https:/ / doi.org/10.1080/09539960902992128 
McCabe, D. L. (2005). Cheating among college and university students: A North American perspective. The International Journal for Educational Integrity, 1(1), 1-11. https:/ / doi.org/10.21913/IJEI.v1i1.14

McCabe, D. L. \& Trevino, L. K. (1993). Honor codes and other contextual influences. Journal of Higher Education, 64, 522-538. https:// doi.org/10.1023/A:1014893102151

McCabe, D. L. \& Trevino, L. K. (1997). Individual and contextual influences on academic honesty: A multicampus investigation. Research in Higher Education, 38, 379-396. https://doi.org/10.1023/A:1024954224675

Meuschke, N. \& Gipp, B. (2013). State-of-the-art in detecting academic plagiarism. International Journal for Education Integrity, 9(1), 50-71.

Meuschke, N., Stange, V., Shcubotz, M. \& Gipp, B. (2018). HyPlag: A hybrid approach to academic plagiarism detection [Paper presentation]. SIGIR '18: The 41st International ACM SIGIR Conference on Research \& Development in Information Retrieval, June 2018, Ann Arbor, Michigan, USA. https:// doi.org/10.1145/3209978.3210177

Mudra, J. \& Dlabolová, D. (2019). Testing of plagiarism detection tools for Czech environment. In Gaižauskaite, I., Bieliauskaite, J. and Valavičiene, N. (Eds.), $5^{\text {th }}$ International Conference: Plagiarism Across Europe and Beyond (pp. 24-26). Mykolas Romeris University.

Newstead, S. E., Franklyn-Stokes, A. \& Armestead, P. (1996). Individual differences in student cheating. Journal of Educational Psychology, 8(2), 229-241.

Oxford University. (2020a). Plagiarism strategy. https:/ /academic.admin.ox.ac.uk/plagiarism-strategy

$\begin{array}{lll}\text { Oxford } & \text { University. } & \text { Plagiarism. }\end{array}$ https://www.ox.ac.uk/students/academic/guidance/skills/plagiarism

Palacký University in Olomouc. (2018). Internal Standard of the Dean of the Faculty of the law of Palacky University in Olomouc on the Formal Requirements for Qualification Theses at the Faculty of Law of Palacky University in Olomouc. PF-B-18/10 of April 2018. https://www.pf.upol.cz/fileadmin/userdata/PF/Studijni_zalezitosti/Rights_and_obligations/PF_B_18 _10_-_Dean_s_Directive_requirements_on_qualification_theses.pdf

Pešek, J. (2014). Podvod jako vážný problem světové vědy i aktuální české historiografie [Cheating as a serious problem within the World and actual Czech historiography]. Český časopis historický, 112(3), 497511.

Plagiarism.org. (2017). What is Plagiarism? https:/ / www.plagiarism.org/article/what-is-plagiarism

Quah, C. H., Stewart, N., \& Lee, J. W. C. (2012). Attitudes of business students' toward plagiarism. Journal of Academic Ethics, 10(3), 185-199. https:// doi.org/10.1007/s10805-012-9157-4

Robinson-Zañartu, C., Peña, E. D., Cook-Morales, V., Peña, A.M., Afshani, R., \& Nguyen, L. (2005). Academic crime and punishment: faculty members' perceptions of and responses to plagiarism. School Psychology Quarterly, 20(3), 318-337. https:/ / doi.org/10.1521/scpq.2005.20.3.318

Roig, M., \& Caso, M. (2005). 'Lying and cheating: Fraudulent excuse making, cheating, and plagiarism', The Journal of Psychology, Vol. 139, No. 6, pp. 485-494.

Smolík, J., Herbočková, L. \& Nesiba, J. (2019). 'Ethics and Plagiarism. Opinion of First-Year Students at University in the Czech Republic', Lifelong Learning - celoživotní vzdělávání, Vol. 9, No. 2, pp. 39-54. https:// doi.org/10.11118/lifele20190902039

Smyth, M. L., \& Davis, J. R. (2004). Perceptions of dishonesty among two-year college students: Academic versus business situations. Journal of Business Ethics, 51(1), 63-74.

Starovoytova, D. (2017). Plagiarism under a magnifying-glass. Journal of Education and Practice, 8(15), 109-129.

Şahin, M., Duman, D. \& Güres, S. (2015). Big business of plagiarism under the guise of (re)translation: The case of Turkey. Babel, 61(2), 193-218. https:// doi.org/10.1075/babel.61.2.03sah

Ural, N. M. \& Sulak, S. A. (2012). Plagiarism via the internet on undergraduate students in Turkey. Journal of Educational and Instructional Studies in the World, 2(3), 229-234.

Vasconcelos, S., Jacqueline, L., Costa, L., Pinto, A. \& Sorenson, M. (2009). Discussing plagiarism in Latin American Science: Brazilian researchers begin to address an ethical issue. EMBO Reports, 10, 677-682. https:// doi.org/10.1038/embor.2009.134

Walker, J. (1998) 'Student Plagiarism in Universities: What are we Doing about it?', Higher Education Research E Development, 17(1), 89-106. https:/ / doi.org/10.1080/0729436980170105

Walker, J. (2009). Measuring plagiarism: researching what students do, not what they say they do. Studies in Higher Education, 35(1), 41-59.

Whitley, B. E. Jr., Nelson, A. B. \& Jones, C. J. (1999). Gender differences in cheating attitudes and classroom cheating behavior: A meta-analysis. Sex Roles, 41(9/10), 657-680. 
Youngsun, K. \& Jaepil, C. (2020). The applicability of aesthetics of appropriation of the discussion on architectural plagiarism. Journal of the Architectural Institute of Korea Planning \& Design, 36(5), 11-22. https://doi.org/10.5659/JAIK_PD.2020.36.5.11 